\title{
Marketing Strategy Analysis To Increase Consumer Satisfaction Using Swotanalysis On Caffein Waroeng Kopi Bojongsari
}

\author{
Fauziah Septiani \\ Economy and Business Faculty, Universitas Pamulang, Indonesia. \\ ${ }^{*}$ Corresponding author: \\ Email: dosen01771@unpam.ac.id
}

\begin{abstract}
.
Marketing has a very important role for trading and service companies. Maintaining excellence, improving service quality by using attractive strategies and appropriate prices in the eyes of consumers is a way to maintain the life cycle of their business. This study aims to determine the marketing strategy in increasing consumer satisfaction using SWOT analysis on Caffeine Waroeng Kopi Bojongsari. This study measures consumer satisfaction with a qualitative method with a phenomenological approach using content analysis and SWOT analysis methods. From the results of the study, the authors carried out a swot analysis by calculating IFAS and EFAS, the recapitulation results obtained that $S W=a$ score of 1.06 and $O T=$ a score of 1.15 this indicates that the company's strategy is in quadrant I. Based on the analysis of strategic factors which can be seen in the SWOT analysis diagram, where Caffeine Waroeng Kopi is in quadrant 1 which shows the SO strategy in the SWOT matrix, namely aggressive strategy. Aggressive strategy is a strategy that uses all strengths to take advantage of opportunities. This strategy is a very profitable strategy because it has opportunities and strengths so that it can be used to progress for Caffeine Waroeng Kopi.
\end{abstract}

Keywords: Marketing Strategy, SWOT Analysis

\section{INTRODUCTION}

Marketing has a very important role for trading and service companies. Maintaining excellence, improving service quality by using attractive strategies and appropriate prices in the eyes of consumers is a way to maintain the life cycle of their business. Based on its function, which in essence seeks to identify what is really needed by consumers, and how to fulfill it, it can be realized. To create a good quality product in the eyes of consumers, it means that the company must also be able to organize and make the right marketing strategy. Facing tough competition is the cafe business. The existence of a caffe in Bojong Sari has become an everyday sight. Caffeine Waroeng Kopi is one of the cafes that attracts attention with its strategic location and unique building located on JL. Raya Parung Ciputat, Bojong Sari, Depok.

The first thing that attracts consumers' attention is the intensity of visitors who come every day, especially at night. In addition, Caffeine Bojong Sari is used as a gathering place for communities in Bojong Sari. The last thing that caught my attention was the events that were often held by Caffeine Waroeng Kopi which attracted consumers to this cafe. The marketing program includes marketing actions that can affect the demand for products, including changing prices, modifying advertising campaigns, designing special promotions and determining distribution channel choices [1] Marketing strategy is also a plan that outlines the company's expectations of the impact of various marketing activities or programs on the demand for products or product lines in certain target markets. In this study, researchers used SWOT analysis in formulating the company's marketing strategy. The SWOT model used is a model that is usually used for strategy formulation research. [2] 


\section{LITERATURE REVIEW Marketing strategy}

Marketing activities are always present in every business, both profit-oriented companies and social enterprises. The importance of marketing is carried out in order to meet the needs and desires of the community for a product or service. Marketing will become more and more important as people's knowledge increases. Then also in order to face competitors who from time to time are increasing. The right strategy for the company can be considered by looking at the internal conditions using the Internal Strategic Factor Analysis Sumary (IFAS) matrix and the External Strategic Factor Analysis Sumary (EFAS) matrix for the company's external conditions. SWOT analysis.

The internal and external environment can be used as an identification of industrial environmental conditions that indicate a marketing strategy that the company can focus on. [3] Based on this description, it is very interesting to examine the internal and external conditions as well as the conditions contained in Caffeine Waroeng Kopi in an effort to increase the company's product sales marketing and can provide good service to consumers.

\section{SWOT concept}

SWOT analysis is used to see the strengths, weaknesses, opportunities and threats that will be faced by the company. By looking at the strengths and developing these strengths, it can be ascertained that the company will be more advanced than existing competitors. Likewise, the weaknesses they have must be corrected so that the company can continue to exist. The existing opportunities must be utilized as well as possible by the company so that sales volume can increase. And the threats that will be faced by the company must be faced by developing a good marketing strategy.

SWOT analysis is the identification of various factors systematically to formulate corporate strategy. This analysis is based on logic that can maximize (Strengths) and (Opportunities), but simultaneously can minimize weaknesses (Weaknesses) and Threats (Threats), [4]. The strategic decision-making process is always related to the development of the company's mission, goals, strategies and policies. Thus, strategic planning must analyze the company's strategic factors (strengths, weaknesses, opportunities and threats) in the current conditions. More in terms of SWOT each part can be seen as follows [5]:

a. Strengths are an advantage of resources, skills or other capabilities relative to competitors and the needs of the market served or to be served by the company.

b. Weaknesses (weaknesses), are limitations or deficiencies in resources, skills and abilities that seriously hinder the effective performance of a company.

c. Opportunities (opportunities), for the company is a favorable situation in the corporate environment. In other words, what business opportunities can be created because of the circumstances that allow for it.

d. Threats (threats), for companies are unfavorable situations that may arise due to environmental factors and government policies. The essence of a well formulated strategy is the right fit between the opportunities and threats facing the company itself.

The preparation of a strategic plan is intended to estimate the shape to the organization of threats (theaters) that must be avoided, strengths (Strengths) owned by the company, weaknesses (Weaknesses) that must be improved towards a better direction and challenge opportunities (Opportunities) that must be utilized as well as possible. -good. SWOT analysis is based on the assumption that an effective strategy will generate strengths and opportunities and minimize weaknesses and threats. Strengths are resources, skills relative to competitors and the needs of the market served by the company, strengths are distinctive competencies that give companies a comparative advantage in the market. 
Strength can be contained in:

a. resource shortage

b. Positive company image

c. Market leadership

d. Buyer relationship with supplier

e. Trust with interested parties. [6]

Opportunity is an important situation that is profitable in a company environment in a business unit. Important trends are a source of opportunity. The environmental conditions that can be utilized include:

a. Important trends that occur among product users. Identify market segments that were previously neglected.

b. Changes in legislation that open up new opportunities in business activities.

c. Changes in the situation and conditions of competition

d. Good relationship with friendly buyers

e. Harmonious supplier relationships Weaknesses are delays or deficiencies in resources, skills and capabilities that hinder the company's effective performance. [7]

In practice, various limitations and shortcomings of these abilities can be seen in:

a. Owned facilities and infrastructure

b. Financial resources

c. Low managerial capability

d. Marketing skills that are not in accordance with market demands

e. Products that consumers do not or are interested in

f. Inadequate level of profit. [8]

A threat is a significant unfavorable situation in a business environment or unit. Threats are a major nuisance to the company's current or desired position. If it is not limited, the threat will become an obstacle for the business unit concerned both now and in the future. Examples of threats include:
a. Entry of new competitors
b. Slow market growth
c. Increased bargaining power of important buyers or suppliers
d. Uncontrolled technological developments and changes
e. Restructive changes to laws and regulations. [9]

\section{METHODS}

Coffee marketing strategy data at Caffeine Waroeng Kopi Bojong sari was collected through field observations, direct interviews with respondents using questionnaires. The focus of the research is a variable that will provide clear boundaries for the things to be researched to answer the existing problems. The analytical method used is descriptive analysis method. Descriptive analysis method is a way of formulating and interpreting existing data so as to provide a clear picture of strengths, weaknesses, opportunities, and threats and also measure consumer satisfaction with a qualitative method with a phenomenological approach using content analysis and SWOT analysis on Caffeine Waroeng Kopi. SWOT analysis is the identification of various factors systematically to formulate company strategy. This analysis is based on logic that can maximize strengths and opportunities, but at the same time minimize weaknesses and threats.

\section{IFAS Matrix}

After the internal strategic factors of a company are identified, an IFAS table is compiled to formulate the internal strategic factors in the Strengths and Weakness framework. 


\begin{tabular}{|c|c|c|c|}
\hline $\begin{array}{l}\text { Factors } \\
\text { Internal Strategy }\end{array}$ & Weight & Rating & Score \\
\hline \multicolumn{4}{|l|}{ Strenghts } \\
\hline - Affordable product prices & 0.20 & 4 & 0.80 \\
\hline - Popular with young people & 0.15 & 3 & 0.45 \\
\hline - Available raw materials & 0.16 & 3 & 0.48 \\
\hline -Easy to carry and practical packaging & 0.21 & 4 & 0.83 \\
\hline -Interesting coffee shop concept & 0.15 & 3 & 0.45 \\
\hline \multirow[t]{2}{*}{$\begin{array}{l}\text {-Availability of complate facilities (wifi, toilat, } \\
\text { prayer room) }\end{array}$} & 0.13 & 3 & 0.39 \\
\hline & 1 & & 3.41 \\
\hline \multicolumn{4}{|l|}{ Weakness } \\
\hline - Low brand awareness & 0.35 & 3 & 1.05 \\
\hline $\begin{array}{l}\text { - Promotional facilities that have not been } \\
\text { maximized, especially for coffee shops that } \\
\text { have just opened }\end{array}$ & 0.15 & 2 & 0.30 \\
\hline $\begin{array}{l}\text { Limited social media success (small number of } \\
\text { followers and not yet wide audience reach) }\end{array}$ & 0.15 & 2 & 0.30 \\
\hline \multirow[t]{2}{*}{ - Another stronger competitor } & 0.35 & 2 & 0.70 \\
\hline & 1 & & 2.35 \\
\hline
\end{tabular}

Fig 1. Matriks IFAS

\section{EFAS Matrix}

Analyze the external environment to find out various possible opportunities and threats that may affect the company's products in the future.

\begin{tabular}{|c|c|c|c|}
\hline $\begin{array}{l}\text { Factors } \\
\text { External Strategy }\end{array}$ & Weight & Rating & Score \\
\hline \multicolumn{4}{|l|}{ Opportunities } \\
\hline - Building new coffeeproduct innovations & 0.25 & 4 & 1 \\
\hline - Building relationships with customers & 0.10 & 3 & 0.30 \\
\hline - Attract new customers with special offers & 0.25 & 3 & 0.75 \\
\hline $\begin{array}{l}\text { - Respond to requests for delivery services (for } \\
\text { example in online motorcycle taxi applications) }\end{array}$ & 0.20 & 3 & 0.60 \\
\hline \multirow[t]{2}{*}{ - Opened an outlet in a new location } & 0.20 & 4 & 0.80 \\
\hline & 1 & & 3.45 \\
\hline \multicolumn{4}{|l|}{ Threats } \\
\hline - Unstable rawmaterial prices & 0.20 & 2 & 0.4 \\
\hline - High level of coffee shop competition & 0.50 & 2 & 1 \\
\hline \multirow[t]{2}{*}{ - Bad ratings from consumers } & 0.30 & 3 & 0.9 \\
\hline & 1 & & 2.3 \\
\hline
\end{tabular}

Fig 2. EFAS MATRIX 


\section{SWOT Analysis Chart}

This study shows that the company's performance can be determined by a combination of internal and external factors. Both of these factors should be considered in the SWOT Analysis. Based on the combination of the company's internal and external factors, the company's current strategic position will be obtained. This strategic position will determine the location of the company's strategic quadrant. The location of these quadrants will be used as a fundamental analysis of future strategies. These quadrants can be clearly observed according to [10] through the following SWOT analysis diagram

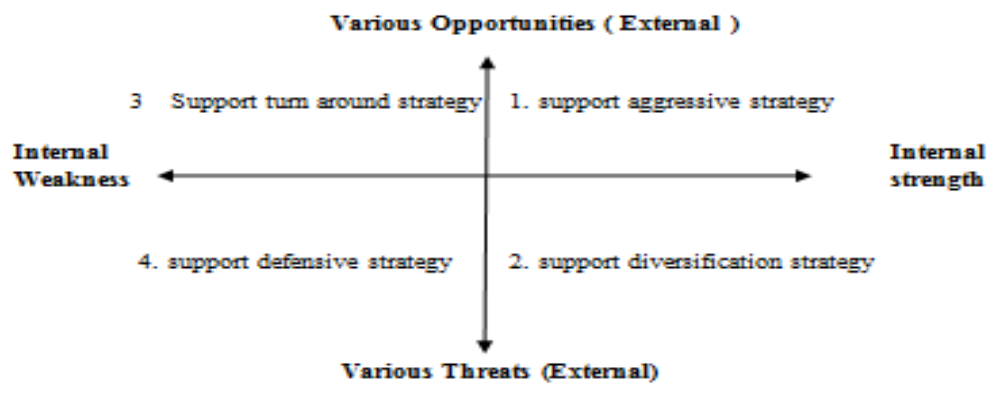

Fig 3. SWOT Analysis Chart

\section{RESULT AND DISCUSSION}

By using the EFAS and IFAS methods, several alternatives emerged in the marketing strategy of Caffeine Waroeng Kopi Bojong Sari:

\begin{tabular}{|c|c|c|}
\hline $\begin{array}{l}\text { IFAS } \\
\text { EFAS }\end{array}$ & $\begin{array}{l}\text { Strenghts } \\
\text {-Affordable product prices } \\
\text {-Popular with young people } \\
\text { - Available raw materials } \\
\text { - Easy to carry and practical packaging } \\
\text { - Interesting coffee shop concept } \\
\text { - Availability of complete facilities (wifi, } \\
\text { toilet, prayer room)| }\end{array}$ & $\begin{array}{l}\text { Weakness } \\
\text { - Low brand awareness } \\
\text { - Promotional facilities that have not } \\
\text { been maximized, especially for } \\
\text { coffee shops that havejust opened } \\
\text { - Limited social media success } \\
\text { (small mumber of followers and not } \\
\text { yet wide audience) Other stronger } \\
\text { competitors }\end{array}$ \\
\hline \begin{tabular}{|l} 
Opportunities \\
- Building new coffee \\
product innovations \\
- Building relationships with \\
customers \\
- Attract new customers \\
with special offers \\
- Respond to requests for \\
delivery services (for \\
example in onlina \\
motorycle \\
applications) \\
Opened an outlet in a new \\
location
\end{tabular} & $\begin{array}{l}\text { Strategy SO } \\
\text { - With affordable product prices, } \\
\text { cafes must build new product } \\
\text { innovations } \\
\text { - Build more relationships with } \\
\text { customers especially most of the } \\
\text { customers are young people } \\
\text { - Using a more complete } \\
\text { distribution chamel using the } \\
\text { rightmarketplace }\end{array}$ & $\begin{array}{l}\text { Strategy WO } \\
\text { - Expanding promotions so that } \\
\text { more young people are interested } \\
\text { in this café } \\
\text { - Redevelop the distribution charnel } \\
\text { using social media }\end{array}$ \\
\hline \begin{tabular}{|l} 
Threats \\
- Unstable raw material \\
prices \\
- High level of coffee shop \\
competition \\
- Bad rating from \\
consumers
\end{tabular} & $\begin{array}{l}\text { Strategy ST } \\
\text { - More stabilizing the price of raw } \\
\text { materials because the demand is } \\
\text { growing steadily } \\
\text { - Increase marketing through social } \\
\text { media } \\
\text { - Maximized service quality }\end{array}$ & $\begin{array}{l}\text { Strategy WT } \\
\text { - Increase brand awareness } \\
\text { - Increase promotion in various } \\
\text { media }\end{array}$ \\
\hline
\end{tabular}

Fig 3. SWOT strategy analysis using IFAS and EFAS 


\begin{tabular}{|l|l|l|l|l|}
\hline \multirow{2}{*}{} & \multicolumn{2}{|l|}{ IFAS } & \multicolumn{2}{l|}{ EFAS } \\
\cline { 2 - 5 } & Strenghts & Weakness & Opportunities & Threats \\
\hline Marketing Strategy & 3.33 & 2.35 & 3.45 & 2.3 \\
\hline Quadrant & $3.33-2.35=1.06$ & $3.45-2.3=1.15$ & \\
\hline
\end{tabular}

Fig 4. IFAS and EFAS Score Recapitulation

Based on the analysis of internal strategy factors that can be seen in the SWOT analysis diagram, where the position of Caffeine Waroeng Kopi is in quadrant 1 which shows the SO strategy in the SWOT matrix, namely aggressive strategy. Aggressive strategy is a strategy that uses all strengths to take advantage of opportunities. This strategy is a very profitable strategy because it has opportunities and strengths so that it can be used for the advancement of Caffeine Waroeng Kopi, cafes should promote more actively and also have to innovate on existing products.

\section{CONCLUSION}

Based on the results of research and discussions that have been carried out on Kapal Api coffee, it can be concluded that the appropriate strategies are aggressive strategies and SO strategies because of Caffeine Waroeng Kopi Bojong Sari coffee. currently has profitable strengths and opportunities, then this strategy is the right one to use for the advancement of Caffeine Waroeng Kopi, such as:

1. By calculating EFAS and IFAS, it is obtained for the S-W strategy a score of 1.06 and O-T got a score of 1.15 , this shows that the company's strategy has opportunities and strengths so that it can take advantage of existing opportunities by carrying out an aggressive strategy.

2. Develop market potential, continue to innovate, continue to carry out more attractive promotions and add variations to existing products.

3. The SWOT analysis shows that the company must better maintain its current image by marketing more through social media because basically this cafe is very popular among young people with existing brands and maintain product quality and maintain consumer trust because it is the most important aspect that must be guarded.

\section{REFERENCES}

[1] Tjiptono, Fandy. 2014, Pemasaran Jasa - Prinsip, Penerapan, dan Penelitian, Andi Offset, Yogyakarta

[2] Inayati, T., Evianah, E., \& Prasetya, H. (2018). Perumusan strategi dengan analisis swot pada usaha mikro kecil menengah. UNEJ e-Proceeding.

[3] Ningrum, 2010. Lingkungan Internal maupun Eksternal. Diunduh pada http://ejournal.undip.ac.id

[4] Rangkuti, Freddy. 2018. Analisis SWOT: Teknik Membedah Kasus Bisnis Cara Perhitungan Bobot, Rating, dan OCAI. Jakarta: PT. Gramedia Pustaka Utama

[5] Darmawan, N., Umar, S., \& Pribadi, H. PEMASARAN BARANG JADI BERBASIS KAYU EBONI DI PERUSAHAAN SUMBER URIP EBONI MELALUI ANALISIS SWOT. Jurnal Warta Rimba, 8(1), 34-41.

[6] Sulistiani, D. (2014). Analisis swot sebagai strategi perusahaan dalam memenangkan persaingan bisnis. el-Qudwah.

[7] Novia, C., Saiful, S., \& Utomo, D. (2021). Analisis SWOT peningkatan daya saing pada UKM keripik nangka di Kabupaten Malang. Teknologi Pangan: Media Informasi dan Komunikasi Ilmiah Teknologi Pertanian, 12(1), 61-69.

[8] Chandra, R. (2019). ANALISIS STRATEGI PERSAINGAN PASAR DENGAN MODEL SWOT PADA RUMAH MAKAN AYAM PENYET PAK ULIS DI LANGSA. Jurnal Penelitian Ekonomi Akuntansi (JENSI), 3(2), 162-173. 
[9] Khamidah, N. (2019). Strategi pengembangan bisnis dengan pendekatan analisis SWOT dalam perspektif ekonomi Islam pada usaha sprei lukis Bali "Mustika” di Kabupaten Batang (Doctoral dissertation, UIN Walisongo).

[10] Rangkuti,Freddy. 2018. Analisis SWOT: Teknik Membedah Kasus Bisnis Cara Perhitungan Bobot, Rating, dan OCAI. Cetakan Keduapuluh Empat. Jakarta: PT Gramedia Pustaka Utama.

[11] Rusdiansyah, R. (2016). Analisis strategi aplikasi penagihan dengan Metode SWOT. Bina Insani ICT Journal, 3(1), $145-153$. 